\title{
Lungfish Neural Characters and Their Bearing on Sarcopterygian Phylogeny
}

\author{
R. GLENN NORTHCUTT \\ Division of Biological Sciences, University of Michigan, \\ Ann Arbor, Michigan 48109-1048
}

\begin{abstract}
The phylogenetic affinity of lungfishes has been disputed since their discovery, and they have variously been considered the sister group of actinistians, the sister group of amphibians, or equally related to actinopterygians and crossopterygians. Previous discussions of these hypotheses have considered neural characters, but there has been no general survey of the nervous systems of sarcopterygians that examines the bearing of neural characters on these hypotheses in the context of a cladistic analysis. Such a survey of representatives of all living sarcopterygian groups reveals at least twentythree characters that are possible apomorphies at some hierarchical level among sarcopterygians. Neural synapomorphies corroborate the phylogenetic hypotheses that actinistians, amphibians, and dipnoans are each monophyletic taxa. The hypothesis that Latimeria is the sister group of amphibians is the least corroborated, as only a single possible synapomorphy, presence of cervical and lumbar enlargements of the spinal cord, supports this hypothesis. The hypothesis that lungfishes are the sister group of amphibians is supported by two possible synapomorphies: loss of a saccus vasculosus and the presence of neurocranial endolymphatic sacs. The hypothesis that actinistians are the sister group of lungfishes is the most corroborated, based on five possible synapomorphies: presence of a superficial isthmal nucleus, a laminated dorsal thalamus with marked protrusion into the third ventricle, olfactory peduncles, evaginated cerebral hemispheres with pronounced septum ependymale, and electroreceptive rostral organs. However, all five characters may be plesiomorphic for bony fishes. The nervous systems of Latimeria and Neoceratodus are very similar to each other, as are the nervous systems of lepidosirenid lungfishes, caecilians, and salamanders. If Neoceratodus is the most plesiomorphic species of living lungfishes, then lepidosirenid apomorphies may have arisen by paedomorphosis. Our inability to examine the neural characters of a relevant outgroup (rhipidistians) may result in many sarcopterygian plesiomorphic characters being interpreted as apomorphic characters, due to the wide distribution of paedomorphic characters among living sarcopterygians and their possible resemblance to plesiomorphic characters present in living outgroups that can be examined.
\end{abstract}

The phylogenetic affinity of lungfishes has been disputed since their discovery in the nineteenth century (see also Conant, this volume). Both lepidosirenid (Fitzinger, 1837; Natterer, 1837) and neoceratodontid (Krefft, 1870) lungfishes were initially described as amphibians. During the next thirty years, many zoologists came to realize that dip- noans were bony fishes and that they were closely allied to fossil fishes such as Dipterus, but their affinities with other fishes were still disputed (Owen, 1841; Günther, 1871;

Dr. Northcutt's present address is Department of Neurosciences, A-001, University of California, San Diego, La Jolla, CA 92093. 
Huxley, 1876; Cope 1887; Dollo, 1896). By the turn of the century, similarities noted between lungfishes and amphibians led most zoologists to believe that lungfishes gave rise to amphibians (Huxley, 1876; Cope, 1884; Haeckel, 1889; Goodrich, '24; Kerr, '32). In 1892 Cope revised his position and argued that amphibians must have arisen from rhipidistian crossopterygians rather than lung. fishes. This viewpoint gained support during the first half of this century (Gregory, '15; Romer, '33; Säve-Söderberg, '35) and was almost universally accepted until Rosen et al. ('81) revived the idea that lungfishes and tetrapods are sister groups.

The neuroanatomical literature, like much of the biological literature, reflects these changing views regarding dipnoan affinities. In most anatomical descriptions of the brains of lungfishes (Beauregard, 1881; Fulliquet, 1886; Wilder, 1887; Sanders, 1889; Burckhardt, 1892; Kerr, '02; Bing and Burckhardt, '04; Elliot Smith, '08; Kuhlenbeck, '24; Holmgren and van der Horst, '25; Gerlach, '33; Rudebeck, '44, '45; Schnitzlein and Crosby, '67, '68; Clairambault and Capanna, '73; Clairambault et al., '74; Thors and Nieuwenhuys, '79) similarities of dipnoan and amphibian brains have been noted, and researchers have frequently assumed that the neural characters exhibited by lungfishes were the characters present in fishes that gave rise to amphibians. With the discovery of a living crossopterygian, Latimeria chalumnae, attention focused on this species (Millot and Anthony, '56, '65, '67; Millot et al., '64; Nieuwenhuys, '65; Lemire, '71; Nieuwenhuys et al., '77; Northcutt et al., '78; Kremers and Nieuwenhuys, '79; Kremers, '81) with the expectation that its brain would reveal many of the primitive neural characters of the crossopterygians. Nieuwenhuys et al. ('77) concluded that Latimeria exhibits neural characters common to the brains of cartilaginous, dipnoan, and ray-finned fishes, but they noted no special structural similarities to the brains of amphibians. Northcutt et al. ('78) noted that the relative size of many of the brain components in Latimeria is more similar to that in amphibians than to that in other fishes, but lungfishes were not included in this analysis. Kremers ('81) analyzed various neural characters of Latimeria in a cladistic context in an attempt to determine the polarity of these characters. His analysis supports the hypothesis that dipnoans and Latimeria are sister groups and that tetrapods are, in turn, the sister group of lungfishes and Latimeria. Kremers ('81) did not examine the brains of amphibians or lungfishes for additional shared derived (synapomorphic) characters but appears to have relied on published accounts of these brains. Similarly, Rosen et al. ('81) included a number of neural characters in their cladistic analysis of sarcopterygian relationships, but they also appear to have relied on the earlier literature rather than examining the nervous systems of these taxa to evaluate presumed synapomorphies or discover potential new ones.

The present study surveys the nervous system in representatives of all living sarcopterygian groups in order to assess previously claimed neural synapomorphies and to search for possible new ones. Further, these synapomorphies are applied in evaluating the following hypotheses of relationships among living sarcopterygians: 1) Actinistians are the sister group of amphibians, and dipnoans are, in turn, their sister group (Fig. 1A); 2) Amphibians are the sister group of dipnoans, and actinistians are, in turn, their sister group (Fig 1B); 3) Actinistians are the sister group of dipnoans, and amphibians are in turn, their sister group (Fig. 1C); 4) Actinistians, amphibians, and dipnoans are equally related. Like that of Rosen et al. ('81), this analysis is based on a number of assumptions: 1) Tetrapods are monophyletic (Gaffney, '79); 2) sarcopterygians (actinistians, dipnoans, and tetrapods), as defined by Rosen et al. ('81), are monophyletic; 3) osteichthyans are monophyletic, and their sister group is the chondrichthyans; 4) actinopterygians are monophyletic and include the chondrosteans and neopterygians; 5) the cladistians (Erpetoichthys and Polypterus) and actinistians are each monophyletic taxa; 6) comparisons among primitive (plesiomorphous) members of each group (Neoceratodus among dipnoans and salamanders among amphibians) should be emphasized (Rosen et al., '81); 7) ray-finned and cartilaginous fishes are considered the relevant outgroups.

\section{MATERIALS AND METHODS}

Perfused brains, or whole heads in the case of smaller specimens, of the species listed in Table 1 were embedded in wax, and serial sections $(15 \mu \mathrm{m})$ were cut in the transverse plane. Sections were subsequently stained with a Nissl stain, cresyl violet, to demonstrate neural somata and/or a modification of 

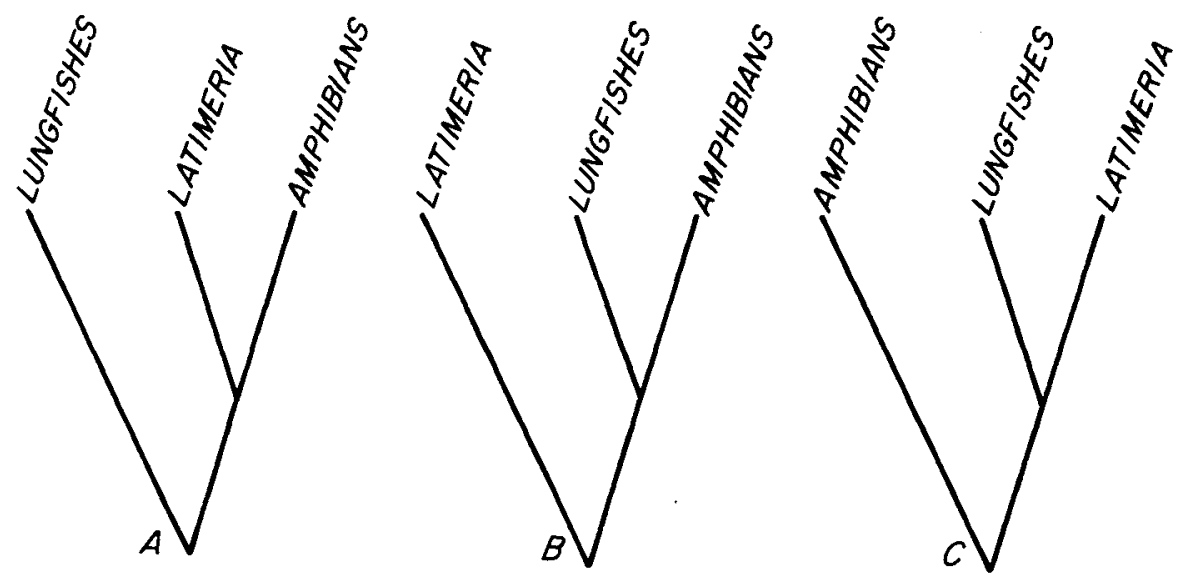

Fig. 1. Three of the four hypotheses regarding the interrelationships of living sarcopterygians. The fourth hypothesis is that the three taxa are equally related.

TABLE 1. Brain and head series examined

\begin{tabular}{cc}
\hline Chondrichthyes & Sarcopterygii (continued) \\
Heterodontus francisci & Dipnoi \\
Hydrolagus colliei & Lepidosiren paradoxa \\
Mustelus canis & Neoceratodus forsteri \\
Notorynchus maculatus & Protopterus aethiopicus \\
Platyrhinoidis triseriata & Protopterus annectens \\
Squalus acanthias & Tetrapoda \\
Squatina dumerili & Ambystoma tigrinum \\
Osteichthyes & Amphiuma means \\
Actinopterygii & Ascaphus truei \\
Amia calva & Cryptobranchus \\
Erpetoichthys calabaricus & alleganiensis \\
Lepisosteus osseus & Hyla crucifer \\
Polypterus palmas & Ichthyophis glutinosus \\
Salmo gairdneri & Nectocaecilia haydee \\
Scaphirhynchus & Necturus maculosus \\
platorynchus & Notophthalmus \\
Sarcopterygii & viridescens \\
Actinistia & Rana catesbeiana \\
Latimeria chalumnae & \\
\hline
\end{tabular}

the Bodian protargol method to demonstrate fiber pathways and peripheral nerves.

Three brains from adult specimens of Latimeria were cut in the transverse plane and stained by variations of the Bodian or Klüver and Barrera methods. Details regarding the collection and preparation of these specimens were reported by Northcutt et al. ('78).

Three brains from adult Neoceratodus were also available for this study. The first speci- men $(6.1 \mathrm{~kg})$, obtained from Dr. S. J. Zottoli and the Research Institute of Alcoholism, Buffalo, New York, was perfused with a mixture of $1 \%$ glutaraldehyde and $2.5 \%$ paraformaldehyde, embedded in paraffin and cut in the transverse plane. Sections from this specimen were stained with cresyl violet. The second and third specimens (gravid females, $8.9 \mathrm{~kg}$ and $10 \mathrm{~kg}$, respectively) were perfused with AFA $(80 \%$ ethanol: $100 \%$ formalin: 
glacial acetic acid, 90:5:5) by Dr. W. E. Bemis; permit and collecting arrangements were made by Drs. J. M. Thomson and Anne Kemp of the Department of Zoology, University of Queensland. The brain of the second specimen was sectioned in the transverse plane, and the third brain was retained whole as a reference specimen. The sections were divided into two sets and stained by the Bodian or Klüver and Barrera methods.

The dorsal views of the brains illustrated in Figures 2-4 were prepared with a Wild M4 dissecting microscope and attached drawing tube. Details of each final drawing were checked against serial sections from that brain before inking was completed.

\section{RESULTS}

A survey of the nervous system in representatives of all living sarcopterygian groups reveals at least twenty-three characters that are possible apomorphies at some hierarchical level among sarcopterygians. The analysis is complicated in part because the brains of living sarcopterygians constitute two phenetic sets. The brain of the Australian lungfish, Neoceratodus (Fig. 3), is far more similar to that of Latimeria (Fig. 2) than to the brains of the lepidosirenid lungfishes, while the brains of lepidosirenid lungfishes (Fig. 4A), caecilians, and salamanders (Fig. 4B) are more similar to each other than they are to the brains of Neoceratodus and Latimeria.

The brains of Latimeria and Neoceratodus are characterized by an extensive cerebellum divided into a central corpus (Figs. 2,3) and laterally paired auricles; lepidosirenids and all amphibians possess brains that are characterized by a small cerebellum (Fig. 4) in which the auricle can be distinguished from the corpus only histologically. Similarly, the midbrain roof in Latimeria and Neoceratodus is relatively large and composed of cellular laminae, whereas the midbrain roof in lepidosirenids, caecilians, and salamanders is relatively small and nonlaminated (Northcutt, et al., '78; Kremers, '81). The overall proportions of the telencephalon, however, are more similar among the lungfishes than between any one dipnoan genus and Latimeria or amphibians.

\section{Dipnoan neural synapomorphies}

The neural similarities between Latimeria and Neoceratodus might suggest that these genera constitute a natural taxon and that dipnoans are paraphyletic. This does not appear to be the case, however, as the living dipnoan genera share four apomorphic neural characters that are not seen in any other group of gnathostomes. The olfactory bulbs in all dipnoans (Figs. 5A,B, 6C) consist

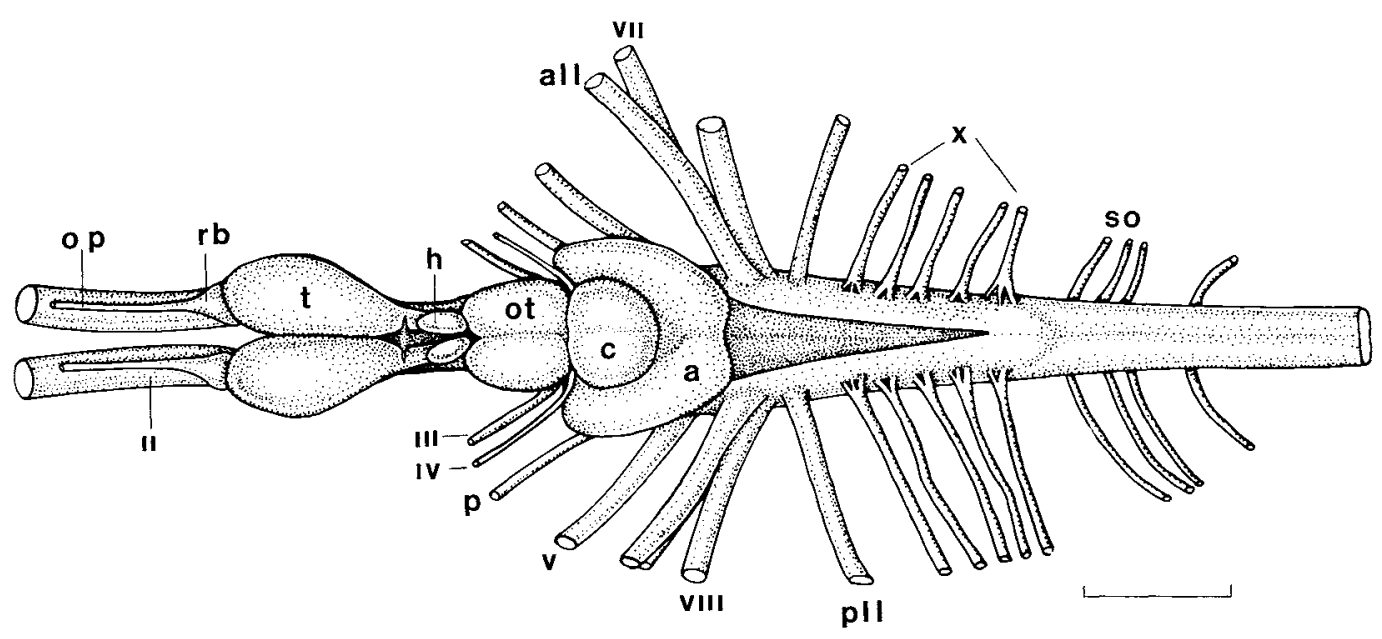

Fig. 2. Dorsal view of the brain of Latimeria chalumnae. Olfactory bulbs of the telencephalon are far anterior and are not pictured. a, auricle of the cerebellum; all, anterior lateral line nerve; c, corpus of the cerebellum; $h$, habenula; op, olfactory peduncle or tract; ot, optic tectum; p, profundus nerve; pll, posterior lateral line nerve; rb, rostral body; so, spino-occipital (hypoglossal) nerves; t, telencephalic hemispheres; II, optic nerve; III oculomotor nerve; $\mathrm{W}$, trochlear nerve; $\mathrm{V}$, trigeminal nerve; VII, facial nerve; VIII, octaval nerve; $\mathrm{X}$, vagus nerve. Bar scale equals $1 \mathrm{~cm}$. 




Fig. 3. Dorsal view of the brain of Neoceratodus forsteri. a, auricle of the cerebellum; all, anterior lateral line nerve; c, corpus of the cerebellum; d, diencephalon; $\mathrm{ob}$, olfactory bulb; op, olfactory peduncle; ot, optic tectum; $\mathrm{pll}$, posterior lateral line nerve; $r$, recurrent ramus of anterior lateral line nerve; so, spino-occipital nerves; t, telencephalic hemisphere; I, olfactory nerve; II, optic nerve; III, oculomotor nerve; IV, trochlear nerve; $V$, trigeminal complex; VII, facial nerve; VIII, octaval nerve; $\mathrm{IX}$, glossopharyngeal nerve; $\mathrm{X}$, vagus nerve. Bar scale equals $1 \mathrm{~cm}$. of a number of concentric layers in the following centripetal order: 1) primary olfactory nerve fibers, 2) glomerular layer, 3) secondary olfactory fibers, 4) internal cellular layer, 5) subependymal fiber plexus, and 6) the ependyma. The subependymal fiber plexus (Fig. 5B) occurs in all dipnoans and in no other known group of gnathostomes. Nothing is known about the nature or functional significance of these fibers in dipnoans.

All dipnoans possess a recurrent ramus of the anterior lateral line nerve (Fig. 3). This ramus courses caudally to run with fibers of the posterior lateral line nerve that distribute to the skin areas around the dorsal, main, and ventral lateral lines of the trunk. The fibers of the recurrent ramus in lungfishes innervate only trunk electroreceptors (Northcutt, '83). Neither Latimeria nor any known amphibian possesses a recurrent ramus of the anterior lateral line nerve, and this character is apparently shared only by lampreys and gymnotoid teleosts. The course and distribution of the recurrent ramus in lungfishes, and an outgroup analysis of this character suggest that it may have been a plesiomorphic character of the earliest vertebrates that was lost with the origin of gna- thostomes and reevolved independently in dipnoans and gymnotids (Northcutt, '85).

All lungfishes are characterized by a distinctly expanded ventral telencephalic floor (Figs. 3, 4A) whose neurons form distinct clusters or islands (Fig. 5C). Traditionally, this region of the telencephalic floor has been considered homologous to the olfactory tubercle in other sarcopterygians. However, recent experimental and immunohistochemical studies indicate that this region in lungfishes does not receive secondary olfactory fibers but does contain fibers and neurons that are comparable to the basal ganglia in other sarcopterygians (Northcutt and Reiner, '85).

All dipnoan genera possess a pair of large neurons, termed Mauthner cells (Fig. 5D), that are located in the reticular formation adjacent to the entry of the octaval nerves into the medulla. In most anamniotes, these cells are characterized by extensive laterally and ventrally directed dendrites and an axon that decussates and courses caudally into the spinal cord as one component of the medial longitudinal fasciculus. Mauthner cell axons in most anamniotes are heavily myelinated and can be traced caudally as a large isolated 

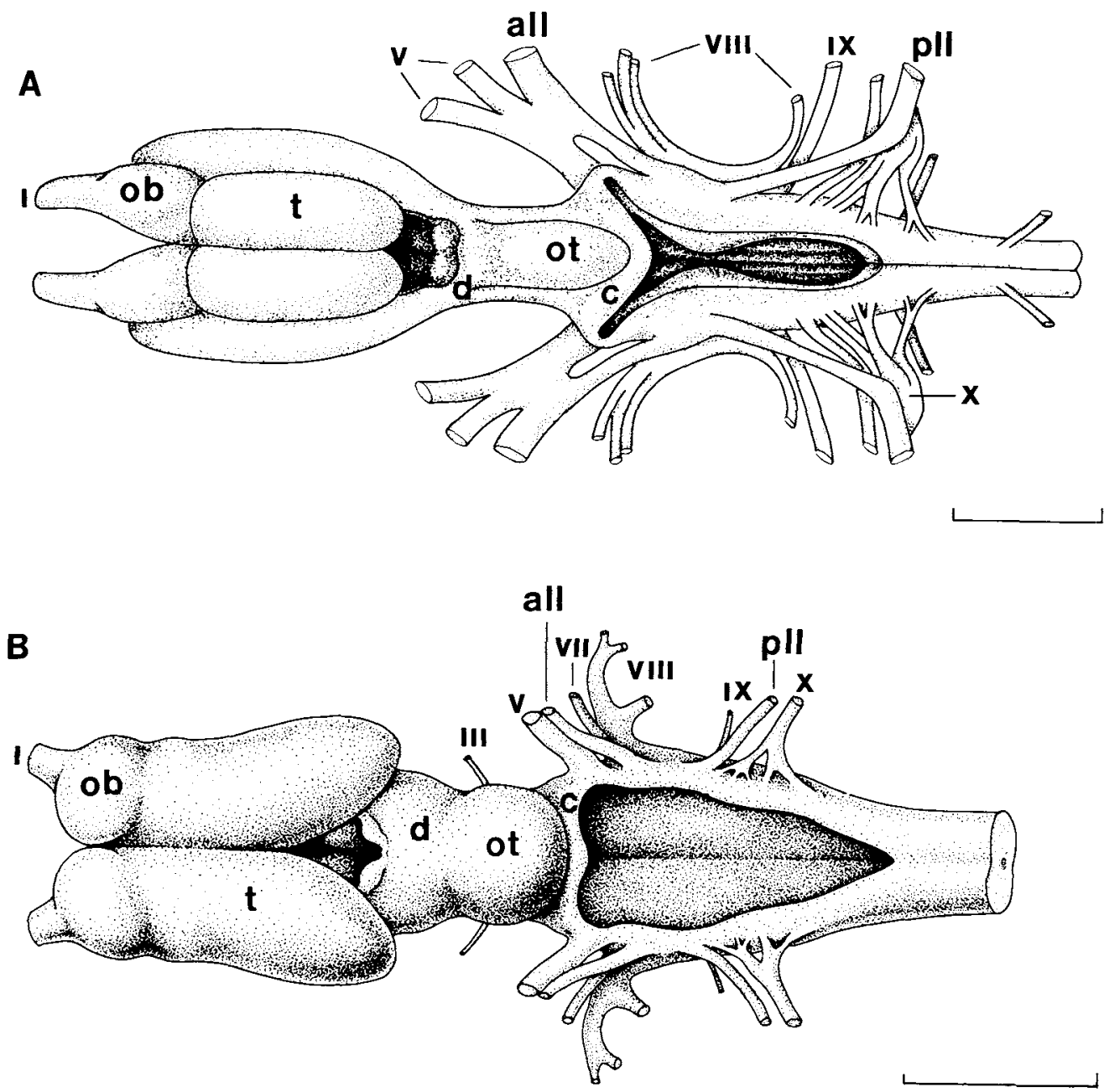

Fig. 4. Dorsal views of the brains of Protopterus annectens (A) and Ambystoma tigrinum (B). all, anterior lateral line nerve; c, cerebellum; d, diencephalon; $o b$, olfactory bulb, ot, optic tectum; pll, posterior lateral line nerve; $t$, telencephalic hemisphere; I, olfactory nerve; III,

fiber. In lungfishes, however, the axon is unmyelinated initially and is closely associated with several axons of additional reticular neurons. The axons of these reticular cells, as well as the axon of the Mauthner cell, are subsequently ensheathed as a single complex (Zottoli, '78). A comparable Mauthner axonal complex has not been described in any other group.

\section{Neural autapomorphic characters of Latimeria}

A survey of the nervous system of Latimeria reveals at least two autapomorphic characters. The telencephalic hemispheres of oculomotor nerve; V, trigeminal complex; VII, facial nerve; VIII, octaval nerve; IX, glossopharyngeal nerve; $X$, vagus nerve. Bar scales equal $5 \mathrm{~mm}(\mathrm{~A})$ and $3 \mathrm{~mm}$ (B).

this species are characterized by a pair of rostrally located lobes termed the rostral bodies (Nieuwenhuys, '65). These are not the olfactory bulbs, which are located immedi-

Fig. 5. Photomicrographs of transverse sections through the olfactory bulb (A and B) of Protopterus; the caudal telencephalon (C) of Protopterus, and the medulla (D) at the level of entry of the octaval nerve in Lepidosiren. In all sections, dorsal and lateral are to the top and left of the figure, respectively. $M$, matrix zone of "standby" cells; Ma, Mauthner neuron; PM, pars medialis of the olfactory bulb; SP, subependymal fiber plexus. Arrows in $\mathrm{C}$ mark neuronal islands of basal ganglia. Magnification of A and C is identical, as is B and D. Bar scales for $\mathrm{B}$ and $\mathrm{C}$ equal $20 \mu \mathrm{m}$ and $50 \mu \mathrm{m}$, respectively. 



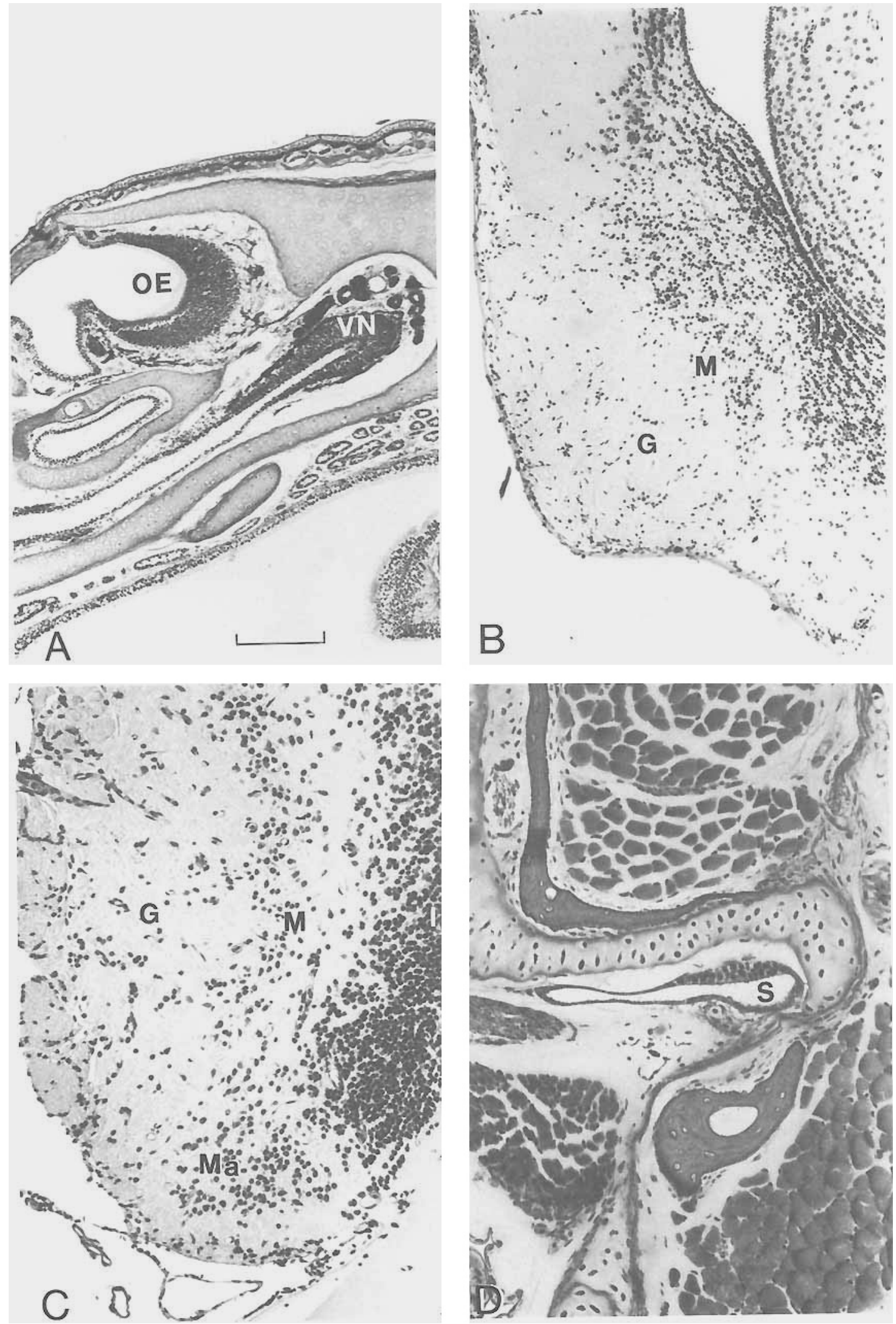
ately adjacent to the olfactory organs, but rostral subdivisions of the cerebral hemispheres (Fig. 2) that appear to receive fibers from the olfactory bulbs via the olfactory peduncles or tracts. The rostral bodies in Latimeria may be homologous to the retrobulbar nuclei in many ray-finned fishes (Kremers, '81); regardless, they constitute a gross anatomical feature of the telencephalon that is unique to Latimeria.

The absence of Mauthner neurons in Latimeria constitutes a second autapomorphy. These neurons are present in aduit lampreys, holocephalians, chondrosteans, many neopterygians, cladistians, dipnoans, and larval as well as many adult amphibians (Ariëns Kappers et al., '36; Zottoli, '78) but apparently do not exist in Latimeria (Kremers and Nieuwenhuys, '79; Kremers, '81). Zottoli (78) claims that Mauthner cells do exist in Latimeria, based on axon identification, but I have not been able to confirm their existence in my own histological preparations.

\section{Amphibian neural synapomorphies}

The olfactory organs in most amphibians (Fig. 6A) are divided into a dorsal main olfactory epithelium and a more ventral sensory epithelium termed a vomeronasal or Jacobson's organ. The vomeronasal organ arises embryonically (Schmalhausen, '68) as a ventrolateral (salamanders) or ventromedial (anurans and caecilians) blind diverticulum that opens directly into a main chamber of the olfactory organ in the adult. The receptors of the epithelium of the main olfactory organ and those of the vomeronasal organ give rise to axons collectively termed the olfactory and vomeronasal nerves, respectively, which terminate in the ipsilateral main and accessory olfactory bulbs, respectively (Northcutt and Kicliter, ' 80 ). The accessory olfactory bulbs in amphibians (Fig. 6B) are located caudolateral to the main olfactory bulbs and are similarly organized in concentric layers in the following centripetal order: 1) primary

Fig. 6. Photomicrographs of transverse sections through the nasal region (A) in $H y l a$, the accessory olfactory bulb (B) in Rana, the ventrolateral portion of the olfactory bulb (C) in Protopterus, and the hyoid pouch (D) in Protopterus. Lateral is toward the left $(\mathrm{B}, \mathrm{C})$ and right $(A, D)$ of the figure and dorsal toward the top. $G$, glomerular layer of the accessory (B) or main (C) olfactory bulb; $\mathrm{I}$, internal cellular layer of the accessory (B) or main (C) olfactory bulb; M, mitral cell layer of the accessory (B) or main (C) olfactory bulb; Ma, matrix zone of olfactory bulb; OE, olfactory organ; S, spiracular organ; VM, vomeronasal organ. Magnification of $\mathrm{A}$ through $\mathrm{D}$ is identical; bar scale equals $20 \mu \mathrm{m}$. nerve fibers, 2) glomerular layer, 3) mitral cell layer, 4) secondary fiber layer, 5) internal cellular layer, and 6) the ependyma. The primary targets of fibers leaving the main and accessory olfactory bulbs are the lateral pallium and the lateral division of the amygdala, respectively (Northcutt and Royce, ' 75 ; Northcutt and Kicliter, '80). Thus the main olfactory and vomeronasal chemoreceptive systems in amphibians maintain separate and parallel pathways within the telencephalon. The vomeronasal system can be recognized peripherally as a distinct ventral diverticulum of the main olfactory organ; centrally, a distinct laterally situated accessory olfactory bulb is present, as is a nucleus in the caudal telencephalon that receives input only from the accessory olfactory bulb.

A distinct vomeronasal system has been recognized in representatives of all three extant orders of amphibians (Northcutt and Kicliter, '80) and in many reptiles and mammals but has not been seen in birds (Ariëns Kappers et al., '36; Northcutt, '81). The peripheral olfactory organs and their neural centers in Latimeria exhibit no features of a vomeronasal system (Millot and Anthony, '65; Nieuwenhuys, '65; Kremers, '81). However, Kerr ('02), Fullarton ('33), and Bertmar ('65) described a "lateral" diverticulum in the embryonic nasal sac of lepidosirenid lungfishes, which led to claims that these fishes possess a vomeronasal organ (Rudebeck, '44; Rosen et al., '81). The "'lateral" diverticulum of the embryonic nasal sac is, in fact, a caudal diverticulum and, in any case, is not topographically comparable to the rostroventral diverticulum that gives rise to the vomeronasal organ in amphibians. The caudal diverticulum in lepidosirenid lungfishes is only one of several transitory diverticuli that occur in embryonic and larval lepidosirenids (Rudebeck, '44), and examination of juvenile and adult specimens of all three dipnoan genera reveal no trace of any diverticuli associated with the olfactory organ. In their study of the telencephalon of Protopterus, Schnitzlein and Crosby ('67) labeled a rostromedial portion of the olfactory organ as a vomeronasal organ. Again, however, my own examination of at least fifty specimens of Protopterus during several experimental studies of the nervous system in this genus has revealed no anatomical specialization within any part of the olfactory sac.

Two distinctly different telencephalic cell groups in lungfishes have been claimed to be homologous to the accessory olfactory bulbs 


in amphibians. Rudebeck ('44) and Schnitzlein and Crosby ('67) described supracortical neurons (Fig. 5A) immediately beneath the pial surface of the telencephalon in lepidosirenid lungfishes as an accessory olfactory bulb; Clairambault and Capanna ('73) described a ventrolateral spherical cell group (Figs. 5A, 6C) in Protopterus as an accessory olfactory bulb. In both Lepidosiren and Protopterus the olfactory nerve divides into lateral and medial fascicles as it forms the implantation cone of the olfactory bulb, and the olfactory axons terminate in distinct lateral and medial glomerular zones (Derivot, '84a). It is this medial zone of the olfactory bulb, or the dorsal pallium immediately caudal to it, that has been termed an accessory olfactory bulb (Rudebeck, '44; Schnitzlein and Crosby, '67). The existence of an accessory olfactory bulb so described would require that the entire medial half of the olfactory nerve and its target be interpreted as a vomeronasal system, whereas the vomeronasal system in amphibians is a distinctly separate nerve that runs ventrolaterally to the olfactory nerve and terminates in a lateral region of the cerebral hemisphere. Finally, experimentally determined efferents of the pars medialis and lateralis of the olfactory bulb in Protopterus exhibit overlap (unpublished observations), which should not be the case if either division were comparable to the accessory olfactory bulb in amphibians.

Clairambault and Capanna ('73) interpreted a rostrolateral group of granulelike cells in the olfactory bulb of Protopterus as an accessory olfactory bulb. However, this cell group does not have any of the internal organization of the accessory olfactory bulb in amphibians, and Derivot ('84b) has recently argued that these cells constitute an embryonic matrix zone composed of "standby" cells that give rise to additional neuronal populations as the olfactory bulb continues to grow throughout life. Thus there

Fig. 7. Photomicrographs of transverse sections through the optic tectum and caudal diencephalon (A) of Platyrhinoidis, the otic capsule and midbrain (B) of Hyla, the midbrain (C) of Protopterus, and diencephalon (D) of Neoceratodus. In all sections dorsal and lateral are toward the top and left of the figure, respectively. D, dura mater; DT, dorsal thalamus; $\mathrm{E}$, endolymphatic sac; $\mathrm{H}$, habenular nucleus; OT, optic tectum; $\mathrm{S}$, superficial isthmal nucleus; I, midbrain tegmentum. Magnification of $A$ and $C$ is identical, as is B and D. Bar scales for A and D equal $50 \mu \mathrm{m}$ and $20 \mu \mathrm{m}$, respectively. is no evidence that lungfishes possess a vomeronasal organ or nerve, nor is there any indication centrally of an accessory olfactory bulb. These observations support the interpretation that a vomeronasal system is a synapomorphy of amphibians.

Paired spiracular organs (Fig. 6D) occur as diverticulae of the hyoid pouches in many nontetrapod gnathostomes. These sensory organs are neuromastlike, are innervated by a ramus of the anterior lateral line nerve, and appear to be mechanoreceptors of unknown specific function (Barry and Boord, '84). Spiracular organs occur in dipnoans, cladistians, chondrosteans, and nonteleost neopterygians (Agar, '06; Norris and Hughes, '20). Latimeria possesses a spiracular chamber, but a spiracular organ was not described in the most complete reports on the anatomy of this animal (Millot and Anthony, '58; '65). It is not clear, however, that the spiracular chamber was specifically examined for the presence of a spiracular organ. Spiracular organs have not been seen in larval or adult amphibians (Noble, '31; Schmalhausen, '68; Jarvik, '80). If Latimeria does possess a spiracular organ, its loss in amphibians should be viewed as an amphibian synapomorphy; if Latimeria does not possess a spiracular organ, its loss in Latimeria and amphibians could be viewed as a synapomorphy linking these two groups.

\section{Possible neural synapomorphies linking two of the three sarcopterygian taxa}

Examination of the nervous systems of living sarcopterygians reveals only a single possible synapomorphy to support the hypothesis that Latimeria is the sister taxon of amphibians (Fig. 1A). In most amphibians and other tetrapods the spinal cord shows enlargements in the cervical and lumbar regions that are associated with innervation of the paired limbs. Similar spinal enlargements associated with the paired fins have been described in Latimeria (Millot and Anthony, '65). Lepidosirenid lungfishes do not exhibit spinal enlargements; to my knowledge, however, the spinal cord of Neoceratodus has not been examined for this character. Thus if Neoceratodus does not exhibit cervical and lumbar enlargements, this pattern could be interpreted as a synapomorphy linking Latimeria and amphibians. However, if such spinal enlargements occur in Neoceratodus, this character should be viewed as a synapomorphy for all sarcopterygian taxa. 
There are at least two possible neural synapomorphies to support the hypothesis that lungfishes are the sister group of amphibians (Fig. 1B): the loss of the diencephalic saccus vasculosus and the presence of an expanded endolymphatic sac containing calcareous crystals associated with the inner ear.

In most cartilaginous and ray-finned fishes, the ependyma of the caudal wall of the posterior tuberculum has an extremely thin evagination termed the saccus vasculosus (Fig. 7A). The saccus, like the pituitary, is closely associated with an extensive vascular system and is suspected to have hormonal functions, but its exact biological role(s) is presently unknown. A saccus vasculosus, albeit rather reduced relative to that in most ray-finned fishes, has been described in Latimeria (Lagios, '75). However, neither dipnoans nor any tetrapods possess a recognizable saccus vasculosus.

In most amphibians, the roof of the otic organ or inner ear exhibits a short duct, termed the endolymphatic duct, a remnant of the embryonic connection of the inner ear with the overlying ectoderm. In lepidosirenid lungfishes and amphibians, the endolymphatic ducts are not rudimentary but expand dorsally and medially to fill much of the neurocranial cavity overlying the midbrain and medulla (Fig. 7B). In some cases these endolymphatic sacs are so extensive that they invade the neural canal of the vertebrae (Dempster, '30; Whiteside, '22). Although these sacs are extremely thin, they are easily recognized by their content of dense calcareous endolymph, and it is possible that they consitute a mechanism to aid sound localization (W. Wilczynski, personal communication). Endolymphatic sacs that invade the neurocranium do not occur in Neoceratodus (Burne, '13) and have not been reported in Latimeria (Millot and Anthony, '65). Thus, although large calcareous-containing endolymphatic sacs of the inner ear may be synapomorphic for lungfishes and amphibians, their absence in Neoceratodus, the most plesiomorphous living dipnoan, suggests that their presence in lepidosirenids and amphibians may be due to parallel homoplasy.

There are five possible neural synapomorphies to support the hypothesis that Latimeria and lungfishes are sister groups (Fig. $1 C)$ : 1) the presence of a superficial isthmal nucleus, 2) the ventricular protrusion of a laminated dorsal thalamus, 3) pedunculated olfactory bulbs, 4) evaginated cerebral hemi- spheres with an extensive septum ependymale, 5) an electroreceptive rostral organ.

In Latimeria (Kremers and Nieuwenhuys, '79) and in all three genera of living lungfishes (Northcutt, '77, '80; Thors and Nieuwenhuys, '79), the rostral isthmus is characterized by a superficial nucleus of small, darkly staining granular cells that lie immediately beneath the pia (Fig. 7C). This superficial isthmal nucleus has been described as the lateral optic cells (Burckhardt, 1892), the isthmal ganglion (Holmgren and van der Horst, '25), and superficial isthmal and mesencephalic grey (Kremers and Nieuwenhuys, '79; Thors and Nieuwenhuys, '79). Although a single similarly situated nucleus does not occur in any other craniate, it is possible that the superficial isthmal nucleus of Latimeria and lungfishes is a field homologue of the tegmental optic nucleus and nucleus isthmi in other vertebrates, as the rostral segment of the superficial isthmal nucleus in lungfishes receives direct retinal input (Clairambault and Flood, '75; Northcutt, '77, '80). This interpretation would be supported if it could be demonstrated experimentally that the caudal segment of the superficial isthmal nucleus in lungfishes has reciprocal connections with the optic tectum. Basal or tegmental optic nuclei in amphibians and teleosts occur at the level of the oculomotor nucleus, whereas nucleus isthmi in amphibians and teleosts occupy a transitional zone in the caudal mesencephalon. Thus the topography of these nuclei in amphibians and teleosts is distinctly different from that of the potential field homologue in lungfishes and Latimeria. If the position of these nuclei in amphibians and teleosts is interpreted as the plesiomorphic condition for sarcopterygians, then the presence of a single superficial nucleus in Latimeria and lungfishes could be interpreted as a synapomorphy.

The dorsal thalamus in lungfishes (Figs. 7D, 9A) and Latimeria (Fig. 8C) exhibits a number of similarities. In each of these taxa the dorsal thalamus protrudes extensively into the third ventricle and is delimited by distinct dorsal and ventral sulci. In each case the periventricular cell bodies of the dorsal thalamus are arranged into distinct laminae, a pattern particularly pronounced in Latimeria (Fig. 8C) and Neoceratodus (Fig. 7D). A dorsal thalamus characterized by a periventricular plate of cells, sometimes laminated, occurs in amphibians (Fig. 9B), as well 


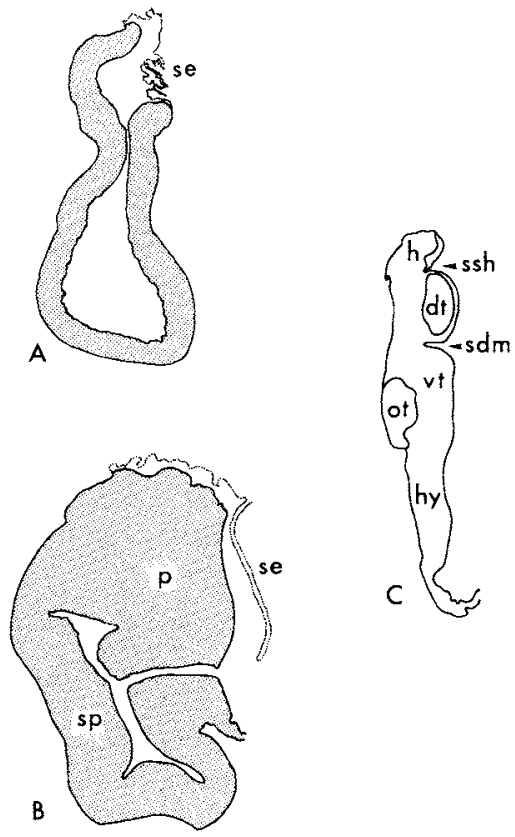

Fig. 8. Diagrams of transverse sections through the cerebral hemisphere (A) in Neoceratodus, and the cerebral hemisphere (B) and diencephalon (C) in Latimeria. Dt, dorsal thalamus; $h$, habenular nuclei; hy, hypothal amus; ot, optic tract; $p$, pallium; sdm, sulcus diencephal. icus medius; se, septum ependymale; sp, subpallium; ssh, sulcus subhabenularis or diencephalicus dorsalis; vt, ventral thalamus.

as cladistians, squalomorph sharks, and lampreys, and is thus the probable plesiomorphic condition for vertebrates. However, in no other vertebrate group does the dorsal thalamus protrude into the third ventricle to the same extent as in Latimeria and lungfishes.

In amphibians and lepidosirenid lungfishes the olfactory bulbs are sessile (i.e., in direct continuity with the cerebral hemispheres, Fig. 4). However, in Latimeria (Fig. 2) and Neoceratodus (Fig. 3) the olfactory bulbs are pedunculated (i.e., located more rostrally in the neurocranium and connected to the hemispheres by distinct olfactory tracts or peduncles). A survey of other living anamniotes reveals sessile olfactory bulbs in hagfishes, lampreys, holocephalians, and all ray-finned fishes except some teleosts. Sessile olfactory bulbs thus appear to be the plesiomorphic pattern and pedunculated bulbs the apomorphic pattern for anamniotes. If the pedunculated olfactory bulbs of Neoceratodus are interpreted as the plesiomorphic condition for lungfishes, their occu- rence in Latimeria and these lungfishes would be interpreted as a synapomorphy.

The cerebral hemispheres in Neoceratodus (Fig. 8A) and Latimeria (Fig. 8B), like those in other sarcopterygians (Fig. 9D) arise embryonically by evagination of the rostrolateral walls of the prosencephalon. In lepidosirenid lungfishes and amphibians the development of the evaginated hemispheres is also marked by an extensive inversion of the dorsomedial roof. This is not the case in $L a$ timeria or Neoceratodus; the hemispheres in these taxa are characterized by an extensive nonneural septum ependymale (Nieuwenhuys and Hickey, '65). The presence of evaginated cerebral hemispheres with an extensive median septum ependymale in $L a-$ timeria and Neoceratodus could be interpreted as a synapomorphy. Ray-finned fishes also possess an extensive septum ependymale, but their hemispheres develop by eversion rather than evagination. Evaginated cerebral hemispheres without a septum ependymale occur in all other living vertebrates and are thus most likely the plesiomorphic condition for vertebrates. However, a septum ependymale may be a synapomorphy of osteichthyans, rather than dipnoans and actinistians, as a reduced spetum ependymale also occurs in the caudal hemispheres in salamanders (Nieuwenhuys, '69).

The snouts of Latimeria and Neoceratodus are characterized by invaginated epithelial sacs, termed the rostral organs and labial cavities, respectively, that may be synapomorphic electroreceptive organs. The rostral organs in Latimeria are extensive mucosal sacs whose epithelium is folded into numerous crypts that are remarkably similar (Bemis and Hetherington, '82) to the electroreceptive ampullary organs in other nonteleost anamniotes. The labial cavities or sacs in Neoceratodus (Günther, 1871; Rosen et al., '81) occupy a site topographically similar to that of the rostral organs in Latimeria, and the sacs in both taxa appear to be innervated by branches of the anterior lateral line nerve. Unfortunately, nothing is known about the histology of the mucosa of the labial sacs in Neoceratodus. If this mucosa is shown to contain ampullary organs, this would suppport the interpretation that the labial sacs and rostral organs are synapomorphies. Similarly, the tentacular organ in caecilians and the nasolacrimal duct in salamanders should be reexamined, as all of these structures may be homologous among sarcopterygians. 

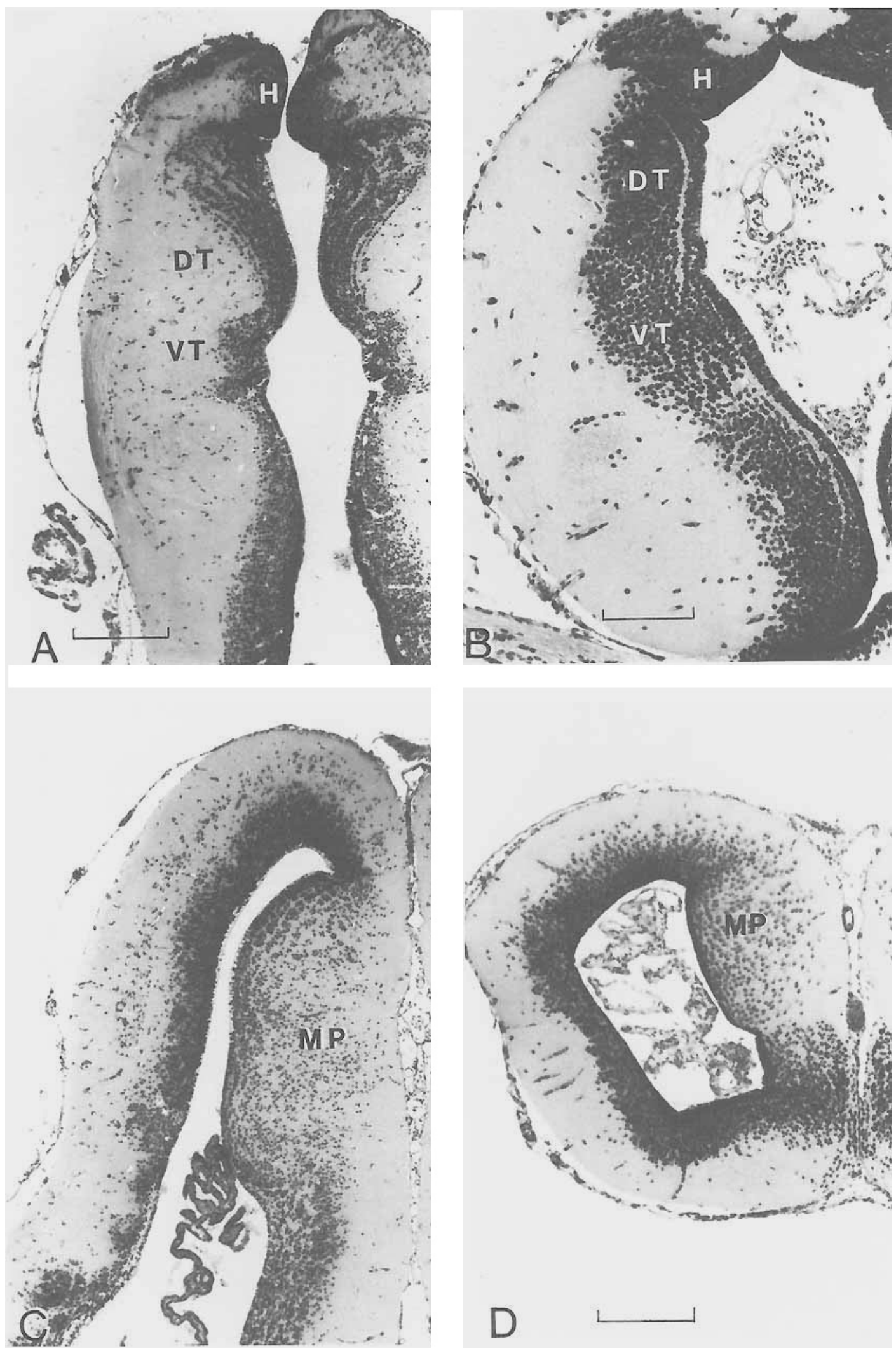


\section{Additional neural apomorphic characters among sarcopterygians.}

The optic tectum in lepidosirenid lung. fishes (Fig. 7A), as well as in caecilians and salamanders (Fig. 7B), is relatively small compared to that in Latimeria (Fig. 2), Neoceratodus (Fig. 3), and anurans. Not only is the tectum relatively small in lepidosirenid lungfishes and non-anuran amphibians, most if not all of its constituent cell bodies are restricted to a periventricular zone rather than being distributed throughout the tectal roof in distinct laminae (Northcutt, '77; Thors and Nieuwenhuys, '79). The tectum in Latimeria (Northcutt and Neary, '75; Kremers, '81) and Neoceratodus (Northcutt, ' 80 ) is relatively larger, distinctly bilobed, and well laminated, as it is in all other craniates. Thus, although a reduced, nonlaminated optic tectum is an apomorphic character of lepidosirenid lungfishes and amphibians, tectal reduction appears to have occurrred independently in these sarcopterygian taxa.

Similarly, the cerebellar corpus in lepidosirenid lungfishes (Fig. 4a) and in all amphibians is relatively small compared to that in Latimeria (Fig. 2), Neoceratodus (Fig. 3), and other gnathostomes. The cerebellar corpus in amphibians and, most likely, lepidosirenid lungfishes appears to represent one of the most striking reductions of a major brain division in any vertebrate (Northcutt et al., '78). Thus a reduced cerebellar corpus in lepidosirenid lungfishes and amphibians is an apomorphic character but appears to have occurred independently.

In all gnathostome vertebrates the cerebellum is divided into a median corpus and laterally paired vertibulolateralis lobes or auricles. In Latimeria (Fig. 2) and Neoceratodus (Fig. 3) the extensive vestibulolateralis lobes are divided into distinct upper and lower leaves, separated by sizable lateral recesses of the fourth ventricle. Similarly organized vestibulateralis lobes occur in cartilaginous and chondrostean fishes (Larsell, '67) and appear to be the plesiomorphic

Fig. 9. Photomicrographs of transverse sections through the thalamus in Protopterus (A) and A mbystoma (B) and the telencephalon in Protopterus (C) and Ambystoma (D). In all sections, dorsal and lateral are toward the top and left of the figure, respectively. DT, dorsal thalamus; $H$, habenular nuclei; $M P$, medial pallium; VT, ventral thalamus. Magnification of $A$ and $C$ are identical. Bar scales equal $50 \mu \mathrm{m}(\mathrm{A}), 20 \mu \mathrm{m}$ (B), and $40 \mu \mathrm{m}$ (D). condition for gnathostomes. The vestibulolateralis lobes in lepidosirenid lungfishes (Fig. 4A) and all amphibian taxa (Fig. 4B) are distinctly different. In these forms the lobes and lateral recesses of the fourth ventricle are barely recognizable, and a distinct ventral leaf can be identified only with difficulty. Thus, while a reduced vestibulolateralis lobe could be interpreted as a synapomorphy for lepidosirenid lungfishes and amphibians, the presence of extensive lobes in Neoceratodus and other gnathostomes suggests that reduction of the vestibulolateralis lobes has occurred independently in lepidosirenid lungfishes and amphibians.

There are at least two distinctly different patterns of organization for the branchiomeric motor nuclei among vertebrates. In all vertebrates the trigeminal motor nucleus is recognizable as a separate nucleus at the rostral end of the branchiomeric motor column. In cartilaginous fishes, however, the remaining branchiomeric motor neurons, whose axons consititute the facial, glossopharyngeal, and vagal nerves, form a single motor column (Smeets et al., '83). A single continuous branchiomeric motor column for neurons of the facial-vagal complex appears to be apomorphic for cartilaginous fishes, as other vertebrates exhibit separate branchiomeric motor nuclei associated with each of these cranial nerves (Nieuwenhuys, '77; Kremers and Nieuwenhuys, '79; Thors and Nieuwenhuys, '79; Nieuwenhuys and Pouwels, '83). Holmgren and van der Horst ('25) claimed that two separate facial motor nuclei (a pars rostralis and pars caudalis) occur in Neoceratodus. However, Gerlach ('33) and Thors and Nieuwenhuys ('79) reported only a single facial motor nucleus in Protopterus and Lepidosiren, respectively. It is possible that some lungfishes, and perhaps other sarcopterygians, exhibit a facial motor pattern different from that in other gnathostomes. However, it is extremely difficult to determine whether a motor nerve arises from one or more nuclei without experimental tracing studies, and resolution of this question will definitely require such investigation.

The roof or pallium of most, if not all, craniates can be divided into lateral, dorsal, and medial components (Northcutt, ' 81 ). The medial pallium in lepidosirenid lungfishes (Fig. 9C) and amphibians (Fig. 9D) forms a distinct ventricularly directed ridge that is characterized by extensive migration of neuronal cell bodies away from the periventri- 
cular zone (Northcutt and Kicliter, '80; Northcutt and Reiner, '85). The telencephalon in Neoceratodus (Fig. 8A) is not characterized by a similarly developed medial pallium (Nieuwenhuys and Hickey, '65). Holmgren and van der Horst ('25) recognized a medial pallial division in Neoceratodus as that portion of the pallium immediately lateral to the dorsal attachment of the septum ependymale, but Nieuwenhuys and Hickey ('65), while noting the same differential thickness of the periventricular zone, concluded that it was due solely to the mechanical effect of the inversion of the hemispheric wall. The existence or absence of a medial pallial component in Neoceratodus will clearly require immunohistochemical or experimental connectional studies for determination. However, it is clear that a distinct medial pallial field, characterized by migrated cell bodies, does not exist in Neoceratodus.

Recognition of a medial pallium in Latimeria is similarly complicated, as the pallium constitutes an expanded solid body protruding into the ventricular cavity (Fig. $8 \mathrm{~B})$. In the caudal portion of this body, distinct lateral, dorsomedial, and ventromedial cellular fields have been recognized (Kremers, '81). If the ventromedial pallial field in Latimeria were demonstrated to be homologous to the medial pallium in other vertebrates, one could argue that a distinctly enlarged medial pallium with migrated cell bodies is a synapomorphy for actinistians and amphibians. If the pallial condition in $\mathrm{NeO}-$ ceratodus is interpreted as the plesiomorphic condition for lungfishes, then a medial pallium with migrated cells in lepidosirenid lungfishes would be considered an independently evolved apomorphic character for lepidosirenids. However, a similarly organized medial pallium also occurs in squalomorph sharks, which suggests that this condition is a symplesiomorphic character for gnathostomes and its absence in Neoceratodus is apomorphic.

In most anamniotic gnathostomes, many of the mechanoreceptive neuromasts of the ordinary lateral line system are housed in canals on the head and trunk (Northcutt, '86). In lepidosirenid lungfishes and amphibians, neuromasts occur in rows or lines that are in the same topographical positions as the canals in other anamniotes. The lateral line system in Lepidosiren and living amphibians is totally devoid of canals, and only a short canal occurs along part of the infra- and supraorbital lines in Protopterus. However, well-developed lateral line canals occur in Latimeria (Millot and Anthony, '65) and in Neoceratodus (Pehrson, '49). Thus reduction or loss of canals associated with lateral line neuromasts appears to have occurred independently as an apomorphic character in lepidosirenid lungfishes and amphibians.

Examination of transverse sections through various levels of the spinal cord in sarcopterygians reveals two basic patterns. The neural cell bodies forming the gray matter of the spinal cords in lepidosirenids, caecilians, and salamanders are distributed around the central canal in an oval pattern with indistinct dorsal and ventral horns. The central gray in Latimeria (Millot and Anthony, '65) and Neoceratodus (Keenan, '28), as well as in anuran amphibians and most other tetrapods, is organized in the wellknown H-pattern with distinct dorsal and ventral horns. The dorsal gray columns are further pronounced in that they are bordered medially and dorsally by an extensive dorsal funiculus. Spinal gray columns with distinct dorsal horns appear to be the plesiomorphic condition for gnathostomes, as this pattern occurs in cartilaginous and ray-finned fishes (Keenan, '28), although the dorsal horns may be fused medially and the dorsal funiculus weakly developed. Thus the presence of distinct dorsal horns and extensive dorsal funiculi in sarcopterygians are symplesiomorphic and synapomorphic characters, respectively. However, reduced or indistinct dorsal horns in lepidosirenids, caecilians, and salamanders are likely an apomorphic character state that has evolved independently.

\section{DISCUSSION}

The present survey of neural characters in living sarcopterygians reveals possible synapomorphies that could corroborate each of the phylogenetic hypotheses illustrated in Figure 10.

The hypothesis that Latimeria is the sister group of amphibians (Fig. 10A) is the least corroborated, as the presence of cervical and lumbar enlargements of the spinal cord is the only possible synapomorphy identified, and it is not clear that the spinal cord of Neoceratodus does not exhibit this character. If spinal enlargements are found to occur in Neoceratodus, the character should be interpreted as a sarcopterygian synapomorphy. The absence of cervical and lumbar enlarge- 
ments of the spinal cord in lepidosirenid lungfishes may well be apomorphic, as this character is correlated with well-developed lateral limbs. The lack of spinal enlargements, the lack of distinct horns of the spinal gray, and filamentous pectoral and pelvic fins without extensive muscles may represent a paedomorphic suite of characters in lepidosirenid lungfishes, caecilians, and many salamanders.

The hypothesis that lungfishes are the sister group of amphibians (Fig. 10B) is supported by two possible synapomorphies: the loss of a saccus vasculosus, and the presence of neurocranial endolymphatic sacs. A saccus vasculosus is a distinct structure that is easily identified, and it is unlikely that there have been errors made in recognizing this character and determining its phylogenetic distribution. The presence of neurocranial endolymphatic sacs is more problematic. While Neoceratodus does possess endolymphatic sacs, they are restricted to the otic capsules (Burne, '13) and do not extend into the neurocranium. Throughout this analysis, I have emphasized comparisons among plesiomorphous taxa; one could therefore conclude that neurocranial endolymphatic sacs have evolved independently in lepidosirenid lungfishes and amphibians. However, the distribution of this character among living sarcopterygians could have resulted from one of three phylogenetic sequences (two independent gains, two independent losses, or one gain and one loss), depending on which phylogenetic hypothesis is valid. Thus it is equally possible that neurocranial endolymphatic sacs in lungfishes and amphibians are synapomorphic or that they are the result of parallel homoplasy. The brain and surrounding tissues of Eusthenopteron, a Devonian rhipidistian, have been reconstructed to show extensive neurocranial endolymphatic sacs (Jarvik, '80). If Jarvik's reconstruction is valid, and if Eusthenopteron is considered a terminal taxon in any phylogenetic hypothesis of sarcopterygian relationships in which lungfishes are not the sister group of all other sarcopterygians, an outgroup analysis leads to the conclusion that neurocranial endolymphatic sacs are a synapomorphic character for sarcopterygians and have been lost in Latimeria and Neoceratodus. Clearly the possible synapomorphy of neurocranial endolymphtaic sacs between Iungfishes and amphibians must be viewed with caution.
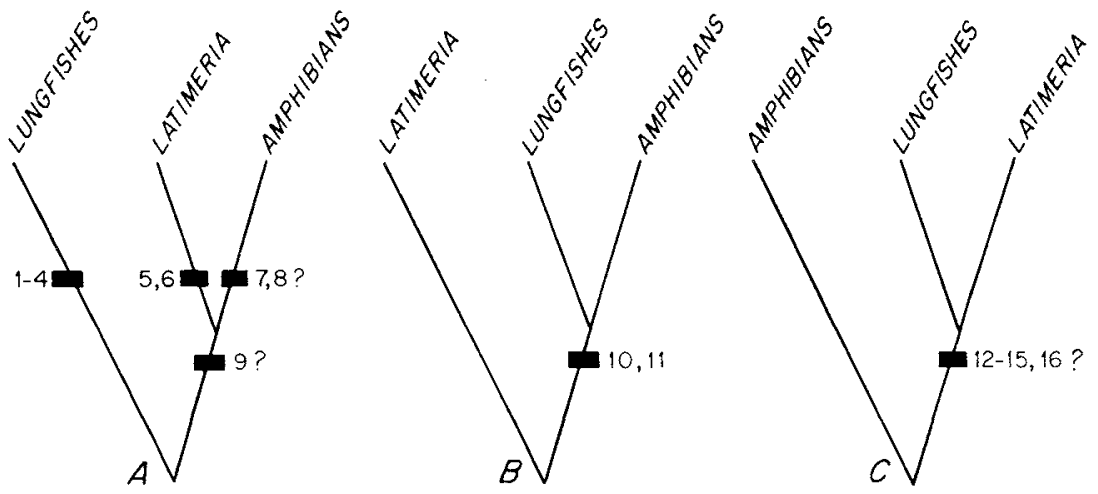

Fig. 10. Cladograms illustrating the three hypotheses of sarcopterygian interrelationships supported by neural characters. The various characters (black bars) interpreted as autapomorphies or possible synapomorphies are indicated at the appropriate level. 1, presence of a subependymal fiber plexus within the olfactory bulb; 2 , presence of a recurrent ramus of the anterior lateral line nerve; 3 , presence of a Mauthner axon ensheathed with reticular axons; 4, presence of cellular islands in the caudal telencephalic floor; 5 , presence of distinct rostral bodies of the telencephalon; 6 , loss of Mauthner neurons;
7 , presence of a vomeronasal system; 8 , loss of spiracular organ; 9 , presence of cervical and lumbar enlargements of the spinal cord; 10 , saccus vasculosus lost; 11 , presence of neurocranial endolymphatic sacs; 12 , presence of a superficial isthmal nucleus; 13 , presence of a laminated dorsal thalamus with marked protrusion into ventricle; 14 , presence of olfactory peduncles; 15 , evaginated cerebral hemispheres with pronounced septum ependymale; 16 , presence of an electroreceptive rostral organ. Question marks denote characters whose distribution is uncertain. 
So far in this analysis, I have considered neural characters only among living sarcopterygians, but it is clear that examination of fossil taxa can be critical, particularly when a very important outgroup (Rhipidistia) is extinct. The problem is particularly vexing if one or more relevant outgroups are extinct and paedomorphic characters are widely distributed in the extant groups, as is evident in considering possible synapomorphies for Latimeria and lungfishes.

The hypothesis that Latimeria is the sister group of lungfish (Fig. 10C) is the most corroborated. However, there are also problems with the interpretation of the characters that constitute their possible synapomorphies.

Determining the polarity of pedunculated versus sessile olfactory bulbs is particularly troublesome. Two phyletic transformations (two gains or two losses) could account for the distribution of these characters, regardless of the actual phylogeny. Emphasis on Neoceratodus as a plesiomorphic taxon would suggest that pedunculated bulbs are a synapomorphy for Latimeria and lungfishes and that sessile bulbs are the plesiomorphic condition for sarcopterygians. Outgroup analysis and ontogenetic precedence would also support this conclusion. However, the brains of Eusthenopteron (Jarvik, '80) and Megalichthys (Romer, '37), Devonian and Carboniferous rhipidistians, respectively, have been reconstructed to show pedunculated olfactory bulbs similar to those of Neoceratodus. While there is considerable risk of error in interpreting brain shape from endocranial casts, the possible presence of pedunculated olfactory bulbs in rhipidistians strongly suggests that this condition is plesiomorphic for sarcopterygians, particularly if additional characters corroborate the hypothesis that rhipidistians are the sister group of amphibians. In this context, the presence of pedunculated olfactory bulbs in Latimeria and Neoceratodus would be interpreted as the retention of a plesiomorphic sarcopterygian trait.

Comparable problems of interpretation plague determination of the polarity of the superficial isthmal nucleus, a laminated dorsal thalamus protruding into the third ventricle, and evaginated hemispheres with a pronounced septum ependymale. While it is extremely probable that these characters are homologous in Latimeria and Neoceratodus, they may be either symplesiomorphies or synapomorphies.
The most obvious conclusion reached after examining the nervous system of living sarcopterygians is that the nervous system of Latimeria and Neoceratodus are very similar to each other, as are the nervous systems of lepidosirenid lungfishes, caecilians, and salamanders. If Neoceratodus is considered the most plesiomorphic species among living lungfishes, then most lepidosirenid apomorphies have apparently arisen by paedomorphosis (see Bemis, ' 84 for evidence that many derived characters among living lungfishes are paedomorphic). It is possible that our inability to examine the neural characters of a relevant outgroup (rhipidistians) that does not exhibit extensive paedomorphic characters leads us to interpret many sarcopterygian plesiomorphic characters as apomorphic characters, due to the fact that the most widely distributed characters among living sarcopterygians are paedomorphic and resemble plesiomorphic characters present in living outgroups that can be examined. Thus a superficial isthmal nucleus, a laminated dorsal thalamus, and evaginated cerebral hemispheres exhibiting a septum ependymale may be plesiomorphic characters for bony fishes that have been retained in Latimeria and Neoceratodus. These considerations suggest that cladistic analyses of soft tissue characters in living groups that exhibit pronounced paedomorphosis are of limited value. Where extensive paedomorphosis exists in extant groups, a cladistic analysis must rely heavily on hard tissue characters whose polarity can be determined by examining fossil taxa.

The possible synapomorphy of the rostral organs of Latimeria and the labial sacs of Neoceratodus is presently very tenuous. While the rostral organs of Latimeria are almost certainly electroreceptive organs (Bemis and Hetherington, ' 82 ), the innervation and function(s) of the labial sacs of Neoceratodus are unknown. In this context, the possible homology of these organs to the tentacular organs of apodans and the nasolacrimal ducts of salamanders is based primarily on topography and only suggests a fruitful area of research.

Finally, Kremers ('81) listed two additional possible synapomorphies linking Latimeria and lungfishes, neither of which appears to be valid: the lack of a bilaterally lobed optic tectum and the presence of an evaginated thinwalled subpallium of the cerebral hemispheres. The optic tectum of Neoceratodus is clearly bilobed (Holmgren and van der Horst, '25; Northcutt, '80), and an evaginated thin- 
walled subpallium is probably a plesiomorphic character of gnathostomes, as it also occurs among cartilaginous fishes.

In summary, a survey of neural characters among living sarcopterygians supports the hypotheses that actinistians, dipnoans, and amphibians are each monophyletic taxa. However, further analysis is complicated by a high frequency of paedomorphic characters in lepidosirenid lungfishes and amphibians. Such characters make it difficult to determine the polarity of the homologies. Most of the neural characters that could constitute synapomorphies for any two of the three living sarcopterygian groups could also be symplesiomorphies for all sarcopterygians, unrecognized as such because of our inability to examine the relevant neural characters in extinct groups. On the basis of neural characters alone, it appears impossible to determine whether amphibians or lungfishes are the sister group of actinistians; such determination must rely on characters for which there is a substantial fossil record.

\section{ACKNOWLEDGMENTS}

I am grateful to Patricia Kay for untiring tenacity in retrieving the literature referenced herein. William L. Fink, Richard L. Puzdrowski, Georg F. Striedter, and Mario Wullimann kindly read the manuscript and have offered insightful and provocative comments in our discussions. Mary Sue Northcutt assisted in many phases of my own research and in the preparation of this paper. The research was supported by $\mathrm{NIH}$ grants NS11006 and EY02485.

\section{LITERATURE CITED}

Agar, W. E. (1906) The spiracular gill cleft in Lepidosiren and Protopterus. Anat. Anz. 28:298-304.

Ariëns Kappers, C. U., G. C. Huber, and E. C. Crosby (1936) The Comparative Anatomy of the Nervous System of Vertebrates, Including Man. New York: Hafner.

Barry, M. A., and R. L. Boord (1984) The spiracular organ of sharks and skates: Anatomical evidence indicating a mechanoreceptive role. Science 226:990-992.

Beauregard, D. H. (1881) Encéphale et nerfs craniens du Ceratodus forsteri. J. Anat. Physiol. 17:1-13.

Bemis, W. E. (1984) Paedomorphosis and the evolution of the Dipnoi. Paleobiol. 10:293-307.

Bemis, W. E., and T. E. Hetherington (1982) The rostral organ of Latimeria chalumnae: Morphological evidence of an electroreceptive function. Copeia 1982:467-471.

Bertmar, G. (1965) The olfactory organ and upper lips in Dipnoi, an embryological study. Acta Zool. Stockholm 46:1-10.

Bing, R., and R. Burckhardt (1904) Das Zentralnervensystem von Ceratodus forsteri. Anat. Anz. 25:588-599.

Burckhardt, R. (1892) Das Centralnervensystem von Protopterus annectens. Berlin: Verlag v. Friedländer \& Sohn.
Burne, R. H. (1913) Note on the membranous labyrinth of Neoceratodus forsteri. Anat. Anz. 43:396-400.

Clairambault, P., and E. Capanna (1973) Suggestions for a revison of the cytoarchitectonics of the telencephalon of Protopterus, Protopterus annectens (Owen). Boll. Zool. 40:149-171.

Clairambault, P., E. Capanna, M. Chanconie, and G. Pinganaud (1974) Architectural pattern of the diencephalon and mesencephalon of the African lungfish Protopterus dolloi. Boll. Zool. 41:107-122.

Clairambault, P., and C. Flood (1975) Les centres visuels primaires de Protopterus dolloi Boulenger. J. Hirnforsch. 16:497-509.

Cope, E. D. (1884) Note on the phylogeny of the Vertebrata. Am. Nat. 18:1255-1257.

Cope, E. D. (1887) Geology and palaeontology. Am. Nat. 21:1014-1019.

Cope, E. D. (1892) On the phylogeny of the Vertebrata. Proc. Am. Phil. Soc. 30:278-281.

Dempster, W. T. (1930) The morphology of the amphibian endolymphatic organ. J. Morphol. 50:71-126.

Derivot, J. H. (1984a) Functional anatomy of the peripheral olfactory system of the African lungfish Protopterus annectens Owen: macroscopic, microscopic, and morphometric aspects. Am. J. Anat. 169:177-192.

Derivot, J. H. (1984b) Functional anatomy of the peripheral olfactory system of the African lungfish Protopterus annectens Owen: development of the primary olfactory pathway during postembryonic growth. Am. J. Anat. 171:15-23.

Dollo, L. (1896) Sur Ia phylogénie des dipneustes. Bull. Soc. Belge Geol. Paleontol. Hydrol. 9:79-128.

Elliot Smith, G. (1908) The cerebral cortex in Lepidosiren, with comparative notes on the interpretation of certain features of the forebrain in other vertebrates. Anat. Anz. 33:513-540.

Fitzinger, L. J. F. J. (1837) Vorläufiger Bericht über eine höchst interessante Entdeckung Dr. Natters in Brasil. Isis, Jena, pp. 379-390.

Fullarton, M. H. (1933) On the development of the olfac tory organ in Protopterus. Proc. R. Soc. Edinburgh 53:1-16.

Fulliquet, G. (1886) Recherches sur le cerveau de Protopterus annectens. Geneve. (cited by Elliot Smith, 1908).

Gaffney, E. S. (1979) Tetrapod monophyly: A phylogenetic analysis. Bull. Carnegie Mus. Nat. Hist. 13:92105.

Gerlach, J. (1933) Über das Gehirn von Protopterus annectens. Anat. Anz. 75:310-406.

Goodrich, E. S. (1924) The origin of land vertebrates. Nature 114:935-936.

Gregory, W. K. (1915) Present status of the problem of the origin of the Tetrapoda, with special reference to the skull and paired limbs. Ann. N.Y. Acad. Sci. 26:317383 .

Günther, A. C. L. G. (1871) Description of Ceratodus, a genus of ganoid fishes, recently discovered in rivers of Queensland, Australia. Phil. Trans. R. Soc. London 161:511-571.

Haeckel, E. (1889) Natürliche SchöpfungsGeschichte. Berlin: G. Reimer.

Holmgren, N., and C. J. van der Horst (1925) Contribution to the morphology of the brain of Ceratodus. Acta Zool. 6:59-165.

Huxley, T. H. (1876) Contributions to morphology. Ichthyopsida No. 1. On Ceratodus forsteri, with observations on the classification of fishes. Proc. Zool. Soc. London pp. 24-59.

Jarvik, E. (1980) Basic Structure and Evolution of Vertebrates, Vol. 1. London: Academic Press.

Keenan, E. (1928) The phylogenetic development of the substantia gelatinosa Rolandi. Part I. Fishes. Proc. R. 
Acad. Amsterdam 31:837-854.

Kerr, J. G. (1902) The development of Lepidosiren paradoxa. Q. J. Mic. Sci. 46:417-459.

Kerr, J. G. (1932) Archaic fishes-Lepidosiren, Protopterus, Polypterus-and their bearing upon problems of vertebrate morphology. Jena Z. Natur. 67:419-433.

Krefft, J. (1870) Description of a gigantic amphibian allied to the genus Lepidosiren, from the Wide Bay District, Queensland. Proc. Zool. Soc. London pp. 221224.

Kremers, J. W. P. M. (1981) The Brain of the Crossopterygian Fish Latimeria chalumnae Smith. Nijmegen: Stichting Studentenpers.

Kremers, J. W. P. M., and R. Nieuwenhuys (1979) Topological analysis of the brain stem of the crossopterygian fish Latimeria chalumnae. J. Comp. Neurol. 187:613638.

Kuhlenbeck, H. 1924 Über die Homologien der Zellmassen im Hemisphärenhirn der Wirbeltiere. 1924 Folia Anatomica Japonica 2:325-364.

Lagios, M. D. (1975) The pituitary gland of the coelacanth Latimeria chalumnae Smith. Gen. Comp. Endocrinol. 25:126-146.

Larsell, O. (1967) The Comparative Anatomy and Histology of the Cerebellum from Myxinoids through Birds. Minneapolis: University of Minnesota Press.

Lemire, M. (1971) Etude architectonique du rhombencé phale de Latimeria chalumnae Smith. Bull. Muséum Nat. D’Histoire Naturelle, sér. 3, no. 2, pp. 41-95.

Millot, J., and J. Anthony (1956) L'organe rostral de Latimeria (Coelacanthidae). Comptes Rendus Acad. Sci. Paris 239:1241-1243.

Millot, J., and J. Anthony (1958) Anatomie de Latimeria chalumnae. Tome I., Squellete, Muscles et Formations de Soutien. Paris: Centre National Recherche Scientifique.

Millot, J., and J. Anthony (1965) Anatomie de Latimeria chalumnae. Tome II., Système Nerveux et Organes de Sens. Paris: Centre National Recherche Scientifique.

Millot, J., and J. Anthony (1967) L'Organisation générale du prosencephale de Latimeria chalumnae Smith (Poisson crossopterygien coelacanthide). In R. Hassler and $H$. Stephan (eds): Evolution of the Forebrain. New York: Plenum, pp. 50-60.

Millot, J., R. Nieuwenhuys, and J. Anthony (1964) Le diencéphale de Latimeria chalumnae Smith (Poisson Coelacanthidé). Comptes Rendus Acad. Sci. Paris 258:5051-5055.

Natterer, J. (1837) Lepidosiren paradoxa, eine neue Gatung aus der Familie der fischähnlichen Reptilien. Ann. Naturhist. Mus. Wien 2:165-170.

Nieuwenhuys, R. (1965) The forebrain of the crossopterygian Latimeria chalumnae Smith. J. Morphol. 117:124

Nieuwenhuys, R. (1969) A survey of the structure of the forebrain in higher bony fishes (Osteichthyes). Ann. N.Y. Acad. Sci. 167:31-64.

Nieuwenhuys, R. (1977) The brain of the lamprey in a comparative perspective. Ann. N.Y. Acad. Sci. 299:97145 .

Nieuwenhuys, R., and M. Hickey (1965) A survey of the forebrain of the Australian lungfish Neoceratodus forsteri. J. Hirnforsch. 7:434-452.

Nieuwenhuys, R., J. P. M. Kremers, and C. van Huijzen (1977) The brain of the the crossopterygian fish Latimeria chalumnae: A survey of its gross structure. Anat. Embryol. 151:157-169.

Nieuwenhuys, R., and E. Pouwels (1983) The brain stem of actinopterygian fishes. In R. G. Northcutt and R. E. Davis (eds): Fish Neurobiology, Vol. 1 Ann Arbor: University of Michigan Press, pp. 25-87.
Noble, G. K. (1931) The Biology of the Amphibia. New York: McGraw-Hill. Republished, 1954, New York: Dover.

Norris, H. W., and S. P. Hughes (1920) The spiracular sense-organ in elasmobranchs, ganoids and dipnoans. Anat. Rec. 18:205-209.

Northcutt, R. G. (1977) Retinofugal projections in the lepidosirenid lungfishes. J. Comp. Neurol. 174:553574.

Northcutt, R. G. (1980) Retinal projections in the Australian lungfish. Brain Res. 185:85-90.

Northcutt, R. G. (1981) Evolution of the telencephalon in nonmammals. Ann. Rev. Neurosci. 4:301-350.

Northcutt, R. G. (1983) The primary lateral line afferents in lepidosirenid lungfishes. Soc. Neurosci. Abstr. 9:1167.

Northcutt, R. G. (1985) The brain and sense organs of the earliest vertebrates: Reconstruction of a morphotype. In R. E. Foreman, A. Gorbman, J. M. Dodd, and R. Olsson (eds): Evolutionary Biology of Primitive Fishes. New York: Plenum, pp. 81-112.

Northcutt, R. G. (1986) Electroreception in non-teleost bony fishes. In T. H. Bullock and W. Heiligenberg (eds): Electroreception. New York: Wiley, pp. 257-285.

Northcutt, R. G., and E. E. Kicliter (1980) Organization of the amphibian telencephalon. In S. O. E. Ebbesson (ed): Comparative Neurology of the Telencephalon. New York: Plenum, pp. 203-255.

Northcutt, R. G., and T. J. Neary (1975) Observations on the optic tectum of the coelacanth, Latimeria chalumnae. Am. Zool. 15:806.

Northcutt, R. G., T. J. Neary, and D. G. Senn (1978) Observations on the brain of the coelacanth, Latimeria chalumnae: External anatomy and quantitative anaIysis. J. Morphol. 155:181-192.

Northcutt, R. G., and A. Reiner (1985) An immunohistochemical study of the telencephalon of the African lungfish. Soc. Neurosci. Abstr. 11:1310.

Northcutt, R. G., and G. J. Royce (1975) Olfactory bulb projections in the bullfrog Rana catesbeina. J. Morphol. 145:251-267.

Owen, R. (1841) Description of the Lepidosiren annectens. Trans. Linnean Soc. London 18:327-361.

Pehrson, T., (1949) The ontogeny of the lateral line system in the head of dipnoans. Acta Zool. 30:153-182.

Romer, A. S. (1933) Vertebrate Paleontology, 1st ed. Chicago: University of Chicago Press.

Romer, A. S. (1937) The braincase of the Carboniferous crossopterygian Megalichthys nitidus. Bull. Mus. Comp. Zool. 82:1-73.

Rosen, D. E., P. L. Forey, B. G. Gardiner, and C. Patterson (1981) Lungfishes, tetrapods, paleontology, and plesiomorphy. Bull. Am. Mus. Nat. Hist. 167:163-275.

Rudebeck, B. (1944) Does an accessory olfactory bulb exist in Dipnoi? Acta Zool. 25:89-96.

Rudebeck, B. (1945) Contributions to forebrain morphology in Dipnoi. Acta Zool. 26:9-156.

Sanders, A. (1889) Contributions to the anatomy of the central nervous system in Ceratodus forsteri. Ann. Mag. Nat. Hist. 3:157-188.

Säve-Söderbergh, G. (1935) On the dermal bones of the head in labyrinthodont stegocephalians and primitive Reptilia. Meddel. Grønland 98:1-211.

Schmalhausen, I. I. (1968) The Origin of Terrestrial Vertebrates. New York: Academic Press.

Schnitzlein, H. N., and E. C. Crosby (1967) The telencephalon of the lungfish, Protopterus. J. Hirnforsch. 9:105-149.

Schnitzlein, H. N., and E. C. Crosby (1968) The epithalamus and thalamus of the lungfish, Protopterus. J. Hirnforsch. 10:351-371. 
Smeets, W. J. A. J., R. Nieuwenhuys, and B. L. Roberts (1983) The Central Nervous System of Cartilaginous Fishes. Berlin: Springer-Verlag.

Thors, F., and R. Nieuwenhuys (1979) Topological analysis of the brain stem of the lungfish Lepidosiren paradoxa. J. Comp. Neurol. 187:589-612.

Whiteside, B. (1922) The development of the saccus endolymphaticus in Rana temporaria Linné. Am. J. Anat.
30:231-266.

Wilder, B. G. (1887) The dipnoan brain. Am. Nat. 21:544 548.

Zottoli, S. J. (1978) Comparative morphology of the Mauthner cell in fish and amphibians. In D. S. Faber and H. Korn (eds): Neurobiology of the Mauthner Cell. New York: Raven Press, pp. 13-45. 